\title{
Pedagogical Competence of Pre-Service Teachers in Implementing PJBL (Project Based Learning)
}

\author{
Natalia Anggrarini \\ natalia.anggrarini@unwir.ac.id \\ English Education Department \\ Wiralodra University, Indramayu
}

\begin{abstract}
This study described and explained the pedagogical competence of Pre service English teachers in Indonesia in implementing Project Based Learning in teaching writing narrative text during apprenticeship program. It described the implementation of Project Based Learning (PJBL) done by pre-service teachers. The steps in project based learning were getting the idea, design the project, tune the project, do the project and exhibit the project. This study used qualitative approach by describing the implementation of the PJBL. The subjects were four teacher candidates of VI semester English Department in Wiralodra University. The findings showed that the concept of PJBL not completely actualized in the classroom. This condition lead to problematic situation for the pre-service teachers. Comprehensive understanding should be taken by pre-service teacher in implementing PJBL in teaching writing narrative text. It is needed to achieve the target of English learning. Thus a deeper understanding of PJBL is needed not only the technical implementation but also cognitive implementation.
\end{abstract}

Keywords: pedagogical competence, pre service teacher, project based learning

\section{INTRODUCTION}

The 2013 curriculum brings a new concept to education in Indonesia, it requires the teachers to implement scientific approach for all subjects includes English subject (Agustin, 2013). Permendikbud No. 81a Tahun 2013 stated that the process of learning in 2013 curriculum is conducting five main learning experiences as observing, questioning, associating, experimenting and networking or so-called scientific approach which is derived from science education framework. Thus in all teaching and learning activities, the teacher should implement this approach for all subjects.

This approach requires the teacher to create activity that arouses students' curiosity, environment-based system, competence-based activity applicative to real life, integrated skill, balance of hard skill and soft skill, and the use of technology. Daryanto(2014) called those activities as the distinctive characteristics of 2013 curriculum. Those activities can be done with several techniques known as Problem-based learning, Project-based learning and Discovery Learning. It expects the students to be actively involved in learning activity. It requires them to learn something from problems, they have to solve by doing learning activity concluded in scientific approach. The Problems are given inform of questions and it should be facilitated by the investigation and dialogue (Arends 2008). The problems should 
be authentic and meaningful to the students. The aim is to enrich students' cognitive models of problems that are presented to them (Dolman and Schmidt 2005, Daryanto 2014).

Project based learning then uses project as the media of learning and produces a publicly-exhibited output such as product, publication or presentation (Thomas 2000, Patton 2012, Daryanto, 2014). In the implementation this learning technique is more complex than problem based learning, as Thomas (2000: 2) stated that project is complex task, based on challenging questions or problems that involve students in design, problem solving, decision making or investigative activities. It gives the students chance to work autonomously in given periods of time. It is usually adjusted to time estimation of the material in syllabus; the range is about three to seven meetings. In the end of meeting, the product is expected ready to be presented or exhibited.

In relation to English teaching and learning, those learning models are expected to create communicative atmosphere in a classroom. To be active in communication, four skills in language should be mastered by the students such as listening, speaking, reading and writing. The mastery of language skills is a prerequisite to overall academic success at every stage of development from childhood to adult years. The mastery of English language should focus on spoken and written language. Derewianka in Agustin (2014) supports the ability of communication focus of two cycles they are spoken and written language. Written language is often seen as the difficult one, writing a text is not always a smooth process (Langan, 1987, Gunning 1998, Parker 1993 as cited in Nik, Hamzah and Rafidee 2011). 2013 curriculum suggests the teacher to design the activity that can cover all the skills in language learning, includes teaching the hardest skill; writing.

The result of preliminary research showed that the implementation of scientific approach with its learning models was considered difficult to be applied in the classroom, especially for teacher candidates of semester VI academic year 2014/2015 faculty of teacher training and education science in Wiralodra University (Wati, 2014). In apprenticeship program, teacher candidates have to be able to transform their competencies as a teacher. As stated in PP No. 19 tahun 2005 tentang Standar Nasional Pendidikan pasal 28 (3) menyatakan bahwa seorang guru harus memiliki kompetensi sebagai berikut: kompetensi pedagogic, kompetensi kepribadian, kompetensi professional dan kompetensi social (a teacher should have these competencies: pedagogical competence, personal competence, professional competence and social competence), it is a must for the teacher candidates to prepare themselves showing the competence of teacher that they have learned in college; making teaching planning, performing, transforming knowledge and showing good behavior.

In accordance with the explanation above, project based learning needs more attention because of its complexity, this study attempts to answer research questions of (1) how did the teacher candidates prepare the teaching and learning activity? (2) how did the teacher candidates implement project based learning in teaching narrative text? (3) how did the teacher candidates solve the problems during the implementation of project based learning in teaching narrative text?. These questions are addressed to meet the objective of the study which is to describe 
and explains the way teacher candidates of semester VI English education in academic year 2014/2015 make the preparation, perform the teaching and learning process and solve the problem during the implementation of project based learning in teaching writing narrative text.

\section{LITERATURE REVIEW \\ Scientific Approach in Language Teaching and Learning}

Scientific approach is an approach that is newly introduced in 2013 curriculum. Basically it is not a new approach; this approach has been used long time ago in science education. Suharyadi (2013) says that SA is old in science but it is new in English language teaching. In the teaching and learning process, scientific approach offers several steps such as observing, questioning, associating, experimenting and networking (syahmadi, 2013). The implementation of scientific approach in learning process involve the process of creativity such as observing, classifying, assessing, predicting, explaining and concluding. This approach is relevant with learning theory proposed by Bruner, Piaget and Vogotsky (Smidt, 2009). The fundamental theories of scientific approach above, there are several techniques can be implemented in language teaching. From Bruner, it leads to discovery learning in learning process, from Piaget it leads to problem based learning and from Vygostsky it leads to Project based learning.

Project Based learning (PJBL) is learning technique that uses project or activity as the media, the students do exploring, assessing, interpreting, synthesizing, answering the question, solving the problem, producing a product, designing product and task (Thomas 2000, Poonpon 2009, Simpson 2011, Daryanto 2014). The projects are complex tasks, built based on challenging questions or problems that involve the students in design, problem solving, decision making, or investigating activity; give the students to work relatively autonomously over extended periods of time; and culminate in realistic product and presentation. Edwards (2002: 3) the lesson plan that is designed by the teacher should consist of several points (1) Lesson Objectives, (2) The Standard, (3) Websites, (4)Prerequisites (skills required to process project), (5) Required Materials, (6) Handout, (7). Required Equipment/Technology.

In education, teacher is viewed as main component in determining the success of education (Barinto, 2012:2). Thus the existence of qualified teacher in improving education is really important. Teacher determines how the success of the students. In his/her hands the students are guided to be what really they are. How good the curriculum in education system, the final execution is on teacher's mind and performance. That why when new curriculum is launched, teacher becomes one who determines it's success. Permendiknas No.16 year 2007 that the competencies of teacher are: 1. Pedagogical competence, 2. Personal competence, 3. Professional competence and 4 social competence. A teacher can be called as qualified teacher when those four main competencies are mastered. 


\section{Pedagogical Competence of Teacher}

Pedagogical competence is an ensemble of potential behaviors / capacities allowing for efficient manifestation of an activity such in teaching planning, execute the interaction or manage learning process and ability to make assessment, or it is viewed as a minimum professional standard, often by law, which professionals should reach drawn from the study of language teaching and language learning (Richard, 2011, Iriana and Andreia 2011, Akhyak et al, 2013). The competencies are teaching plan competency, learning and teaching process competency, learning and teaching assessment and evaluation competency.

In teaching language, teacher should pay attention on the skills of language; listening, speaking, reading and writing. Writing is viewed as the process of gathering ideas and working with it until they are presented in a manner that is polished ad comprehensible to the reader, it is the combination of process and product ( Linse 2006, Harmer 2007, Sokolik 2003). In teaching writing teacher can uses different number of approaches: process approach and product approach (Harmer, 2007). A process approach aims to get the heart of the various skills that should be employed when writing. This approach asks the students to consider the procedure of putting together a good piece of work. In product approach, the focus is on the product of the writing. The aim is put in the task and the end product.

In teaching writing, teacher is expected to teach genre. One of genre taught is narrative text. Narrative is one of genre in writing that should be mastered my the students in senior high school. In constructing narrative text, Anderson (1997:8) states that there are several steps can be done; orientation, complication, , sequence of event/climax and resolution.

\section{RESEARCH METHOD}

This study is describing and explaining a phenomenon among the students of English Department semester VI in Wiralodra University who took apprenticeship in senior high school. The case was they have to be able to perform their teaching competencies within the issue of curriculum change. In this case, the writer described a phenomenon, as Yin (1984) in Nunan (1992) and Marshall and Rossman (2006) see that as a case study. This study aimed to describe and explain a phenomenon under the implementation of Project based learning by teacher candidates of English department in their apprenticeship program. The subjects of this study were four teacher candidates semester VI English department academic year 2014/2015 in Wiralodra University who took apprenticeship program in four different schools. To get the data from this study, the writer employed several instruments they were observation, questionnaire and depth interview. 


\section{FINDING AND DISCUSSION}

To get the data from this study, the writer employed several instruments they were Observation, questionnaire and depth interview. The main information is taken from observation, the researcher came to each class to know the real teaching and learning process to find out the real information related to the pedagogical competence of teacher candidates in implementing project based learning in teaching writing. The second and third data are taken from questionnaire and interview to confirm the field notes.

Data from Document (Lesson plan)

The $1^{\text {st }}, 2^{\text {nd }}, 3^{\text {rd }}$ and $4^{\text {th }}$ teacher candidates have made their own lesson plan, three of them made with the guidance of their guru pamong, while one of them made by taking sample from the internet. Three of them have similar format where the in this case scientific approach form dominate the lesson plan and one of them design the lesson plan by mentioning the detail of project steps. In term of points in the lesson plan, one teacher candidate did not mention the time allocation; two others did not mention the assessment and evaluation while for the other one completely put all points in the lesson plan. This happened because of the teacher candidate who did not mention the time allocation misunderstood about the learning method. The understanding of project based learning was simply as giving assignment, can be seen that this teacher candidate did not understand project based learning very well. The other teacher candidates basically have understood project based learning only one of them who was not aware to the school schedule so she missed one meeting for the exhibition.

Data Field Notes, Questionnaire and Depth Interview

The data was about the implementation of project based learning in the classroom. The main data was taken from field notes where the writer observed directly in the classroom. The analysis was supported by the data from questionnaire and dept interview.

The $1^{\text {st }}, 2^{\text {nd }}, 3^{\text {rd }}$ and $4^{\text {th }}$ have done the implementation of scientific approach. All of them implemented the steps well although there need betterment to connect from one step to the next steps. During they implement scientific approach, they also implement project based learning. The finding showed that the first teacher candidate did not implement project based learning instead problem based learning. She believed that it was project but there was no step of tuning the project, do the project and exhibit the project. she explained about the assignment the students have to do. In this case she still did not understand about project based learning.

The $2^{\text {nd }}$ and the $4^{\text {th }}$ conducted the step of monitoring in the classroom. In this case they can see the progress of the students in doing the project. The $2^{\text {nd }}$ teacher candidate did the exhibit step and got the product from the students although some of students' groups did not collect the product on time while for the $4^{\text {th }}$ teacher candidate did not held exhibition for the project, it happened because she did not predict the time carefully. The schools did not allow teaching and learning activity because of it was national examination day. 
The $3^{\text {rd }}$ teacher candidate conducted monitoring outside the classroom, he did by text and social media. He checked the progress by checking via text message as well as media social. It seemed this method was not successfully lead the students to the creation of the product. It was proved on exhibition day. There were no group that collected the product. He kept conducting the presentation but no assessment for the product.

\section{Problems and Solution}

From the finding, the problems occurred during the implementation of project based learning were class management and the implementation of some steps in project based learning. In term of class management the teacher candidates managed the class carefully by set them by group and monitored them one by one (groups). It seemed tiring but the teacher candidates at least can see all groups' problem in doing the project. In term of the steps in project based learning, the writer found that some problems might happen in the future were tune the project, do the project and exhibit the project.

\section{CONCLUSION AND SUGGESTION}

From the finding and discussion it can be concluded that teacher candidates should understand deeper more and do careful preparation as well as the implementation of project based learning. In term of the steps in project based learning; tune the project, do the project and exhibit the project, it is better for the teacher to provide the sample of the project, and do monitoring in the classroom and give more feedback (assessment and evaluation) for the product as well as the students' performance.

\section{REFERENCES}

Agustien, Helena.I.R.2006. The 2013 English Curriculum: The Paradigm, A Paper Presented at Surakarta: SebelasMaret University Press

Agustien, Helena.I.R.2013. Scientific Approach dan Genre Based Approach A Paper Presented at Seminar BulanBahasa FBS UNES, 24 Oktober 2013

Akhyak, Idrus, M., \& Bakar, Y. A. 2013. Implementation of Teachers Pedagogy Competence to Optimizing Learners Development in Public Primary Schoolin Indonesia. IJER (International Journal of Education and Resarch) , 10 .

Anderson, M. 1997. Text Type in English 2. Australia: Mackmillan.

Arends, R. I. 2008. Learning to Teach 7th Edition. New York: Mc. Graw Hill.

Atweh, B., \& Abadi. 2009. Investigating Teachers Pedagogical Beliefs In Indonesaand Australia. Curtin University of Technology, 15. 
Brown, H. D. Teaching By Principle. An Introduction Approach to Language Pedagogy. New Jersey: Prentice Hall Regents.

Castranova, J.A. 2000. Discovery Learning for The $21^{\text {st }}$ Century.

Daryanto. 2014. Pendekatan Pembelajaran Saitifik Kurikulum 2013. Yogyakarta: Gava Media.

Edwards, G. J. 2002. Make Your Own Project Based Lesson Plan. United States: Star Schools.

Eric, A. H., \& Steven. 2000. Teacher Quality and School Reform in New York. National Bureau of Economic Research.

Ezemach, D., \& Islam, C. 2005. Paragraph Writing from Sentence to Paragraph.Oxford: Mac Millan.

Foss, Patric., Carney, Nathaniel., McDonal, Kurtis., \& Rooks, Matthew. 2004. Project-Based Learning Activities for Short-Term Intensive English Programs. Asian EFL Journal. 19

Harmer, J. 2001. How To Teach English. Edinburgh: Longman.

Harmer, J. 2004. How to Teach Writing. England: Pearson.

Harmer, J. 2007. The Practice of English Language Teaching 3rd Edition. England: Longman.

Hung, Chung-Ming., Hwang, Gwo-Jen., Huang, Iwen. 2012. A Project-based Digital Storytelling Approach for Improving Students' Learning Motivation, Problem-Solving and Learning Achievement. Education Technology and Society. 12

Iriana, Andrea \& Mata, Liliana. 2011. Pedagogical Competence - The Key to Efficient Educaion. IOJES, 13.

Karolina, I. 2006. Teaching Narrative Text in Improving Writing to Tenth Grade Students of SMA Neg. 1 Petarukan Pemalang. Semarang: Semarang State University

Klein, Joel. L., Tavera, Santiago., King, Sabrina Hope., Comitante, Anna., et al. 2009. Project Based Learning: Inspiring Middle School Students to Engage in Deep and Active Learning. New York: NYC Dep of Education.

Kornwipa, P. 2009. Enhancing English Skills Through Project Based Learning. Thailand: Khon Kaen University.

Laksmi, E. D. 2006. "Scaffolding" Students' Writing in EFL Class: Implementing Process and Product Approach. TEFLIN, 16. 
Linse, C., Vlack, S. V., \& Bladas, O. 2014. Parents and Young Learners in English Language Teaching. British: British Counsil Press.

Ministry of Education Malaysia. 2006. Project Based Learning Handbook. Pesiaran Bukit Kiara: Kuala Lumpur

Neo, E. 2005. Narrative for O Level. Malaysia: Longman.

Newman, M.J. 2015. Problem Based Learning: An Introduction the Overview of The Key Features of The Approach. Journal of Veterinary No. 12.

Nikolaeva, S. 2012. Improving Initial Teacher Education By Using The Project Based Approach. Education Research Journal , 15.

Nuryani, V. 2014. Improving Students Ability in Writing Narrative Text Through Scientific Approach. Suryakencana University.

Patton, A., \& Robin, J. 2012. Work That Matter: The Teacher's Guide to Project Based Learning. The Paul Hamlyn Foundation.

Richard, J. C. 2011. Competence and Performance in Language Teaching. USA: Cambridge University Press.

Richard, J. C., \& Thomas, S. F. 2005. Professional Development for Language Teachers. New York: Cambridge University Press.

Sagala, S. 2007. Management Strategik Peningkatan Mutu Pendidikan. Jakarta: Alfabeta.

Simpson, J. 2011. Integrating Project Based Learning in an English Language Tourism Classroom in a Thai University. North Sydney: Australian Cathollic University.

Thomas, J. W. 2000. A Review of Research on Project Based Learning. California: The Autodesk Foundation.

Triono, S. 2014, December Saturday 6). Liputan6. Retrieved January Wednesday 21, 2015, from Liputan6.com: http:/www.liputan6.com

Wati, A. 2014. The Scientific Approach in Teaching Speaking for Various Text. Semarang: Semarang State University. 